\title{
Penerapan Model Pembelajaran Scramble dalam Meningkatkan Aktivitas dan Hasil Belajar Matematika Pada Peserta Didik Kelas V SD
}

\author{
Reski Setia Amalia ${ }^{1}$ Muhammad Ilham ${ }^{2}$, Muh. Syarwa Sangila ${ }^{3}$ \\ ${ }^{1}$ Institut Agama Islam Negeri Kendari, Indonesia. E-mail: setia7898@gmail.com \\ ${ }^{2}$ Institut Agama Islam Negeri Kendari, Indonesia. E-mail: muhammadilham@iainkendari.ac.id \\ ${ }^{3}$ Institut Agama Islam Negeri Kendari, Indonesia. E-mail: syarwa1990@gmail.com
}

\begin{tabular}{l}
\hline \multicolumn{1}{c}{ Articel info } \\
\hline Artikel history: \\
Received: 26 Oktober 2020 \\
Revised:26 Desember 2020 \\
Accepted: 3 Juni 2021
\end{tabular}

\begin{abstract}
This study aims to improve students' mathematics learning activities and outcomes by applying the Scramble-type cooperative learning model in grade V SDN SATAP 02 Konsel in the 2019/2020 school year. This type of research is a classroom action research conducted in two. The PTK Kurt Lewin Scheme was used in this research which includes planning, implementation, observation and reflection. Data collection techniques were observation sheets, tests, and documentation which were analyzed descriptively. The results showed that the application of the Scramble learning model can improve the learning activities of class V SDN SATAP 02 Konsel. The results of the observation sheet activity of students in cycle I was $67 \%$, then increased to $86 \%$ with the Very Good category in the cycle two. Besides, the use of such method can improve the results of students' mathematics learning. Before the treatment, the average students' learning score was 64.46 with $60 \%$ completeness. After the first cycle, the average learning score reached to 77.25 with completeness of $75 \%$. Then the learning outcome rose to 82.25 with $81.25 \%$ completeness in cycle II.
\end{abstract}

Penelitian ini bertujuan meningkatkan aktivitas dan hasil belajar matematika peserta didik dengan menerapkan model pembelajaran kooperatif tipe Scramble di kelas V SDN SATAP 02 Konsel pada tahun ajaran 2019/2020. Jenis penelitian ini adalah penelitian tindakan kelas yang dilaksanakan sebanyak dua siklus. Prosedur penelitian menggunakan skema PTK Kurt Lewin meliputi perencanaan, pelaksanaan, pengamatan dan refleksi. Teknik pengumpulan data menggunakan lembar observasi, tes, dan dokumentasi yang dianalisis secara deskriptif. Hasil penelitian menunjukkan bahwa penerapan model pembelajaran Scramble dapat meningkatkan aktivitas belajar kelas V SDN SATAP 02 Konsel. Hasil lembar observasi aktivitas peserta didik pada siklus I mencapai 67\%, kemudian meningkat pada siklus II mencapai $86 \%$ dengan kategori Sangat Baik. Selain itu, dengan penerapan model pembelajaran Scramble, hasil belajar matematika peserta didik juga mengalami peningkatan. Sebelum tindakan, nilai rata-rata hasil belajar peserta didik sebesar 64,46 dengan persentase ketuntasan 60\%. Setelah tindakan siklus I, nilai rata-rata siswa 77,25 dengan persentase ketuntasan $75 \%$. Kemudian pada siklus II, hasil belajar peserta didik kembali meningkat dengan nilai rata-rata 82,25 dan persentase ketuntasan $81,25 \%$.

\section{Keywords:}

Keywords satu;

Keywords dua;

Keywords tiga;
Scramble

Aktivitas belajar,

Hasil belajar Matematika 


\section{PENDAHULUAN}

Pendidikan merupakan hal yang sangat penting dalam membangun bangsa. Pendidikan adalah salah satu cara untuk membangun sumber daya manusia yang berkualitas. Redja Mudyahardjo (2012) bahwa pendidikan adalah segala pengalaman belajar yang berlangsung dalam lingkungan dan sepanjang hidup. Pendidikan adalah segala situasi hidup yang memengaruhi pertumbuhan dan perkembangan individu. Melalui pendidikan, manusia memperoleh ilmu pengetahuan dan pengalaman yang sangat berguna bagi kelangsungan hidupnya. Sebagaimana dalam Undang-Undang No. 20 Tahun 2003 pasal 3 dijelaskan bahwa "Pendidikan nasional berfungsi mengembangkan kemampuan dan membentuk watak serta peradaban bangsa yang bermartabat dalam rangka mencerdaskan kehidupan bangsa, bertujuan untuk mengembangkan potensi peserta didik agar menjadi manusia yang beriman dan bertakwa kepada Tuhan Yang Maha Esa, berakhlak mulia, sehat, berlimu, cakap, kreatif, mandiri dan menjadi warga Negara yang demokratis dan bertanggung jawab" (UU RI N0.20 Tahun 2003,h.8).

Tujuan pendidikan memiliki fungsi bagi bangsa dan negara, tujuan pendidikan menggambarkan kondisi akhir atau aspek-aspek yang ingin dicapai dari proses pendidikan. Seperti yang dikatakan oleh Sardiman (2011) bahwa tiga jenis tujuan belajar yaitu untuk mendapatkan pengetahuan, penanaman konsep dan keterampilan, serta pembentukan sikap. Atas dasar tersebut tentu dapat dipahami bahwa harapan pendidikan nasional merupakan suatu kewajiban pemerintah agar mengusahakan hal-hal yang dibutuhkan dan mengembangkan sistem pendidikan yang bermutu demi menjamin hak para peserta didik. Komponen pendidikan adalah tujuan, peserta didik, manajemen, struktur dan jadwal waktu, isi bahan ajar, guru, media belajar, hingga biaya pendidikan. Dari beberapa komponen yang disebutkan sebelumnya maka salah satu komponen penting dalam pendidikan adalah guru. Guru dalam dunia pendidikan mempunyai peranan yang besar. Tugas utama guru ialah mengajar yang membantu peserta didik untuk mencapai tujuan dalam beberapa bidang studi, kemudian tidak lupa dengan melakukan perbaikan mutu pendidikan untuk meningkatkan persentase ketuntasan belajar dan kelulusan peserta didik. Salah satu hasil belajar yang perlu ditingkatkan ialah mata pelajaran Matematika. Sebab Matematika salah satu bidang studi yang selalu ada dalam penentuan kelulusan peserta didik pada jenjang pendidikan dan menjadi pembahasan melihat banyak peserta didik yang banyak memiliki hasil belajar yang belum mencapai KKM .

Dari hasil observasi di SDN SATAP 02 Konawe Selatan tahun ajaran 2019/2020. Salah satu kelas yang hasil belajar Matematika paling banyak belum mencapai KKM yaitu kelas V sebanyak 10 peserta didik, persentase ketuntasan hanya $60 \%$ dari jumlah 16 orang dengan nilai KKM Matematika di sekolah adalah 65. Selain itu, peneliti melihat beberapa kali dalam proses pembelajaran Matematika di kelas $\mathrm{V}$ guru hanya masuk memberikan materi dan contoh soal saja, kemudian menyuruh peserta didik mengerjakan beberapa nomor soal yang wajib dikumpul sebelum jam istirahat dan banyak peserta didik yang melihat pekerjaan temannya lalu mengumpulkan tugasnya. Jadi, dapat dilihat aktivitas peserta didik perlu ditingkatkan agar mereka lebih terlibat dalam kegiatan belajar Matematika. Adapun yang menjadi alasan peneliti menjadikan subjek penelitian di kelas $\mathrm{V}$ bukan kelas lain adalah karena berdasarkan observasi dan wawancara yang dilakukan peneliti yang menunjukkan bahwa kelas tersebut; (1) terdapat masalah pada jumlah peserta didik yang paling banyak belum mencapai KKM hasil belajar matematika sebanyak 10 orang, (2) kurangnya aktivitas peserta didik dalam pembelajaran matematika, sehingga perlu melakukan tindakan dan upaya agar mencapai kegiatan belajar yang dapat meningkatkan aktivitas peserta didik agar dapat memngaruhi hasil belajar. Sebab semakin tinggi tingkat aktivitas belajarnya maka peserta didik tersebut dapat memperoleh kemampuan kognitif yang tinggi pula (Kursiyati, 2011).

Peneliti melihat beberapa materi pembelajaran yang belum dilaksanakan pada kelas V sebelum melakukan penelitian yaitu jaring-jaring kubus, volume bangun ruang kubus dan balok serta penyajian 
data. Namun yang sering menjadi momok bagi peserta didik khususnya peserta didik sekolah dasar adalah bangun geometri yang di dalamnya membahas mengenai bangun datar dan bangun ruang. Sebagaimana jurnal yang dibaca oleh peneliti dengan judul "Analisis Kesalahan Mengerjakan Soal Geometri pada peserta didik Kelas V SD/MI di Kota Jogjakarta" menunjukkan bahwa peserta didik SD cenderung mengalami kesulitan dalam mengerjakan soal matematika tentang bangun geometri. Maka dalam penelitian ini peneliti memilih materi volume bangun ruang kubus dan balok.

Slameto (2015) menjelaskan bahwa hasil belajar yang diperoleh dari serangkaian proses belajar pada dasarnya dipengaruhi oleh dua faktor yakni faktor internal dan eksternal. Salah satu faktor eksternal yang memengaruhi hasil belajar ialah metode ataupun model yang digunakan pada pelaksanaan pembelajaran. Salah satu model yang cocok pada materi soal volume bangun ruang kubus dan balok adalah Scramble. Langkah-langkah Scramble sangat cocok digunakan dengan melihat karakteristik dan kemampuan peserta didik. Seperti pada salah satu hasil penelitian yang telah dilakukan mengenai model pembelajaran Scramble oleh Fiana Puspa Nursenda "model pembelajaran Scramble dapat meningkatkan hasil belajar IPS pada peserta didik kelas V SDN Perning Mojokerto. Penelitian ini dilakukan dua tahap yaitu siklus I dan II. Pada siklus I aktivitas guru hanya $70 \%$, dan pada siklus II meningkat menjadi $88,75 \%$. Sedangkan hasil belajar peserta didik pada siklus I hanya 77\%, dan pada siklus II meningkat mencapai 93,3\%" (Fiana Puspa Nursenda, 2018, h. 229). Menurut Hanafiah dan Suhana (dikutip dalam Nur, 2011) model pembelajaran Scramble adalah model pembelajaran yang bersifat aktif, peserta didikdituntut aktif bekerja sama serta bertanggung jawab terhadap kelompoknya untuk menyelesaikan kartu soal guna memperoleh poin dan diharapkan dapat meningkatkan kebersamaan peserta didik. Melalui metode penugasan dengan model pembelajaran kooperatif tipe Scramble, peserta didik dituntut untuk belajar berkelompok agar dapat mengatasi kesulitan dalam menyelesaikan soal secara individual untuk mencapai tujuan bersama serta dapat mengerjakan soal secara mandiri jika diberikan latihan soal oleh guru.

\section{METODE}

Penelitian ini dilaksanakan selama dua siklus sesuai dengan prosedur pelaksanaan PTK Kurt Lewin yaitu identifikasi, perencanaan, pelaksanaan, pengamatan dan refleksi. Penelitian ini dilaksanakan pada semester genap tahun ajaran 2019/2020 dimulai pada tanggal 8 Februari sampai 29 Februari. Adapun tempat penelitian ini adalah di kelas V SDN SATAP 02 Konsel desa Sindangkasih Kec. Ranomeeto Barat.Sedangkan subjek penelitian dalam penelitian ini adalah peserta didik kelas V SDN SATAP 02 Konsel yang berjumlah 16 orang peserta didik yang terdaftar pada tahun ajaran 2019/2020 pada semeter genap.

Tabel 1. Pedoman kriteria persentase aktivitas belajar

\begin{tabular}{cc}
\hline Tingkat Persentase (\%) & Predikat \\
\hline $86-100$ & Sangat Baik \\
$76-85$ & Baik \\
$60-75$ & Cukup Baik \\
$55-59$ & Kurang Baik \\
$\leq 54$ & Kurang Baik Sekali
\end{tabular}

Adopsi dari Ngalim Purwanto, 2009

Teknik pengumpulan data dalam penelitian ini dilakukan dengan menggunakan tiga metode yaitu menggunakan lembar observasi, tes, dan dokumentasi. Indikator kinerja yang dicapai dalam penelitian ini apabila peserta didik mencapai standar keberhasilan atau ketuntasannya sebagaimana 
yang telah ditetapkan pada standar Kriteria Ketuntasan Minimal (KKM) sekolah tersebut yaitu apabila peserta didik memperoleh nilai $\geq 65$, maka peserta didik dinyatakan telah mencapai ketuntasan secara individual atau perorangan dan ketuntasan secara klasikal dinyatakan telah berhasil apabila mencapai $70 \%$.

Untuk mengetahui persentase aktivitas belajar peserta didik: $\mathrm{Np}=\mathrm{R} / \mathrm{SM} \times 100 \%$

Keterangan:

$\mathrm{Np} \quad=$ Nilai persentasi yang dicari atau diharapkan

$\mathrm{R}=$ = Jumlah skor mentah yang diperoleh peserta didik

$\mathrm{SM}=$ Skor Maksimum ideal tes yang digunakan

$100=$ Bilangan tetap. (Ngalim Purwanto, 2010)

Dalam menentukan nilai rata-rata perolehan hasil belajar menggunakanrumus: $\mathrm{X}=\Sigma \mathrm{xi} / \mathrm{N}$

Keterangan:

¿xi $\quad=$ Jumlah nilai yang diperoleh setiap peserta didik

$\mathrm{N} \quad=$ Jumlah seluruh peserta didik di dalam kelas

$\mathrm{x} \quad=$ Nilai rata-rata yang diperoleh. (Husein Umar, 2014)

Untuk menentukan persentase ketuntasan hasil belajar peserta didik menggunakan rumus:

$\mathrm{P}=(\Sigma \mathrm{fi}) / \mathrm{N} \times 100 \%$

Keterangan:

$\mathrm{P} \quad=$ Persentase peningkatan

$\mathrm{N}=$ Jumlah seluruh peserta didik di dalam kelas

$\Sigma \mathrm{fi} \quad=$ Jumlah peserta didik pada kategori ketuntasan belajar. (Supardi, 2006)

Untuk mengetahui peningkatan ketuntasan belajar peserta didik menggunakan rumus:

$\mathrm{P}=($ Posrate-Baserate $) /$ Baseratex 100\%

Keterangan:

Posrate = Nilai yang sudah diberikan tindakan

Baserate $=$ Nilai sebelum tindakan .

(Zainal Akib, dkk, 2001)

\section{HASIL DAN PEMBAHASAN}

\section{HASIL}

\section{Aktivitas Belajar}

Pada siklus I, aktivitas belajar peserta didik mengalami peningkatan setelah diterapkannya model pembelajaran Scramble yaitu 58\% pada pertemuan pertama dan $67 \%$ pada pertemuan kedua dengan kategori cukup baik. Peningkatan ini didorong oleh peserta didik yang sudah mulai terbiasa dengan proses kegiatan pembelajaran menggunakan model Scramble dan mampu bekerja sama dengan baik. Namun masih terlihat beberapa peserta didik kurang terlibat dalam kegiatan belajar dan hanya mengharapkan temannya untuk mengerjakan soal yang diberikan oleh guru. Pada Siklus II, aktivitas belajar peserta didik baik itu pada pertemuan pertama atau kedua mengalami peningkatan yang begitu signifikan setelah diterapkannnya model pembelajaran Scramble. Peningkatan aktivitas belajar peserta didik pada pertemuan pertama sebesar $79 \%$, dan naik menjadi $86 \%$ pada pertemuan kedua dengan kategori sangat baik. Fenomena ini terjadi karena keterlibatan peserta didik dalam pembelajaran sangat tinggi, sehingga terjadi interaksi yang efektif antara guru dan peserta didik, juga antara sesama peserta didik itu sendiri. Selain itu, peserta didik yang berkemampuan tinggi sudah terbiasa mengajak anggota kelompoknya bekerja sama dengan baik sehingga tugas yang diberikan oleh guru mudah dan cepat terselesaikan. Bagan peningkatan aktivitas belajar peserta didik dapat dilihat pada gambar 1 . 


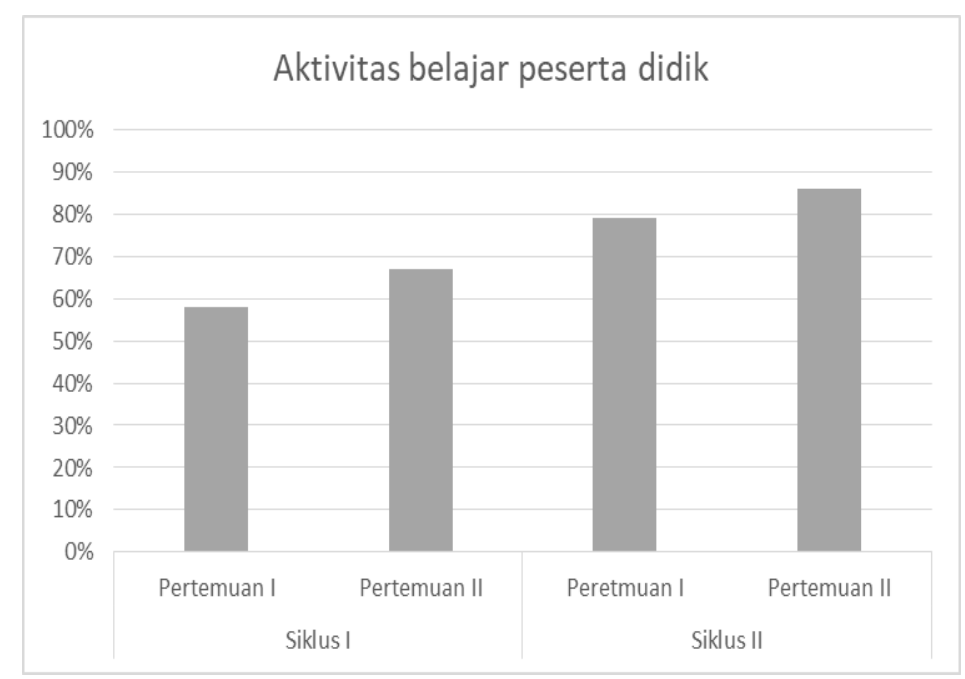

Gambar 1 Peningkatan Aktivitas Belajar Peserta Didik

\section{Nilai Hasil Belajar}

Sebelum dilakukan tindakan, dari 16 peserta didik yang mengikuti tes hasil belajar, terdapat 10 peserta didik belum mencapai nilai ketuntasan belajar (nilai $\geq 65$ ) sedangkan peserta didik yang tuntas hanya sebanyak 6 orang. Pada siklus I model pembelajaran Scramble telah diterapkan dan terlihat 12 peserta didik telah mencapai nilai KKM, namun jumlah peserta didik yang tidak mencapai KKM sebanyak 4 orang. Ketuntasan secara klasikal pada siklus I mencapai 75\% dengan rata-rata 77,25. Peningkatan hasil belajar peserta didik dari pra siklus ke siklus I adalah sebesar $25 \%$.

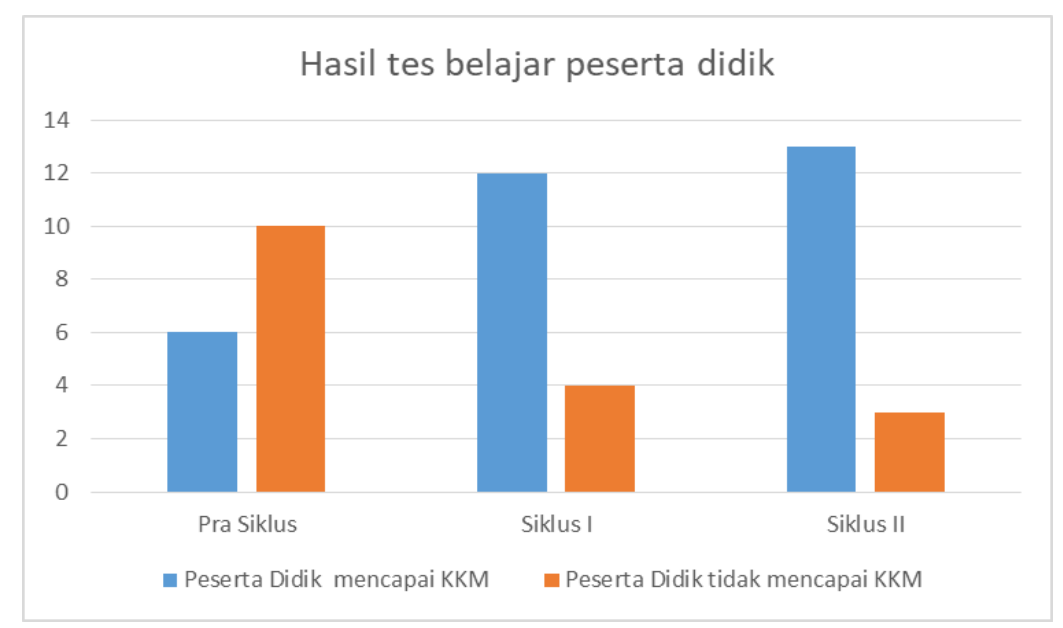

Gambar 2 Hasil tes belajar peserta didik dari pra tindakan ke tindakan

Pada Tindakan siklus II terjadi peningkatan jumlah siswa yang telah mencapai nilai KKM yaitu menjadi 13 peserta didik, namun jumlah peserta didik yang tidak mencapai KKM sebanyak 3 orang. Ketuntasan secara klasikal pada siklus II mencapai 81,25\% dengan rata-rata 82,25. Peningkatan hasil belajar peserta didik dari pra siklus ke siklus II adalah sebesar 35\%. Hasil tes belajar peserta didik dapat diamati pada gambar 2. 


\section{PEMBAHASAN}

\section{Aktivitas Belajar Peserta Didik}

Pelaksanaan tindakan dilakukan pada siklus I dan II yang dilaksanakan masing-masing dua kali pertemuan. Untuk pemberian skor aktivitas belajar peserta didik dilakukanselama proses pembelajaran berlangsung.Penilaian aktivitas belajar ini dilakukan dengan tujuan untuk mengetahui sejauh mana perkembangan aktivitas belajar peserta didik selama proses pembelajaran melalui penerapan model pembelajaran Scramble. Muzakar (2014) bahwa kegiatan belajar yang dilaksanakan pada suatu sekolah merupakan faktor yang memengaruhi kualitas sekolah tersebut. Kemudian Nana Sudjana (2010) mengatakan bahwa perilaku keaktifan peserta didik yang dapat dinilai dalam proses belajar yaitu mencari dan memberi informasi, bertanya pada guru atau peserta didik lain, diskusi atau memecahkan masalah, mengerjakan tugas yang dikerjakan oleh guru, dapat memecahkan masalah secara tepat, ada usaha dan motivasi untuk mempelajari bahan pelajaran atau stimulus yang diberikan oleh guru, bisa bekerja sama dan berhubungan dengan orang lain dan senang apabila diberi tugas belajar.Analisis dan refleksi aktivitas peserta didik dalam kegiatan pembelajaran sebelum tindakan pada dasarnya aktivitas peserta didik masih kurang dan perlu ditingkatkan dimana aktivitas mereka di dalam kelas hanya mencatat, mengerjakan soal lalu mengumpulkannya. Setelah tindakan dilakukan, maka keaktifan belajar menunjukkan usaha yang dilaksanakan melalui pembelajaran kooperatif memberikan dampak positif. Peningkatan tersebut disebabkan manajemen pembelajaran kooperatif telah berjalan dengan baik dan efektif setelah melakukan refleksi. Antusias peserta didik muncul sejak awal penerapan model tersebut.

Peningkatan aktivitas dari siklus I ke siklus II ditandai dengan pemanfaatan pembelajaran kooperatif membuat suasana kelas sudah tenang, bisa diatur dan kondusif sehingga pembahasan pembelajaran Matematika dapat berlangsung dengan baik dan tidak membosankan, pada saat diskusi di kelas melaksanakan model Scramble juga sudah berjalan dengan baik dan mendapatkan respon positif dari peserta didik dengan antusias menjawab soal-soal dengan baik dan benar, serta mau mengerti untuk saling membantu pada anggotanya. Pada diskusi kelompok terlihat sudah ada interaksi yang baik antar anggota dan mau bekerja sama sehingga semua anggota dapat terlibat dalam diskusi. Peserta didik yang memiliki akademik yang tinggi secara langsung mengajak temannya agar memahami isi soal dan bagaimana cara menjawabnya dengan benar. Hal ini dikarenakan, model pembelajaran kooperatif memiliki beberapa keunggulan, yaitu mengurangi ketergantungan peserta didik terhadap guru, memberdayakan peserta didik untuk lebih bertanggung jawab dalam belajar, meningkatkan prestasi akademik, dan meningkatkan aktivitas belajar peserta didik (Wina Sanjaya, 2013: 249-250). Pembiasaan mengerjakan soal secara kooperatif ini yang menuntut semua peserta didik harus mengerti soal dan bisa maju menuliskan jawabannya di papan tulis, membuat mereka antusias ketika membahas soal pekerjan rumah yang diberikan oleh guru beberapa nomor pada pertemuan selanjutnya dan berani menuliskannya di depan. Adanya peningkatan aktivitas tersebut sejalan dengan pendapat Piaget dalam Hakim (2011) bahwa seorang anak itu berpikir sepanjang ia berbuat. Maka sangat penting keaktifan peserta didik dalam pembelajaran agar ia dapat melatih cara berpikirnya. Hal ini dapat disimpulkan dari hasil pengamatan selama penelitian dan melihat hasil dari peneliti-peneliti sebelumnya bahwa model pembelajaran Scramble dapat meningkatkan aktivitas belajar peserta didik. Hasil tersebut didukung denganpenelitianInes Desi Handini (2012) bahwa dengan menggunakan model pembelajaran Scramble dapat meningkatkan aktivitas belajar peserta didik Kelas VII D SMP Negeri 1 Alian.

\section{Hasil Belajar Peserta Didik}

Purwandari (2015) pemilihan model pembelajaran di sekolah harus mampu meningkatkan proses pembelajaran peserta didik, sehingga hasil belajar peserta didik dapat memenuhi KKM yang 
ditetapkan sekolah. Model pembelajaran Scramble ini menggunakan penekanan latihan soal berupa permainan yang dikerjakan secara berkelompok agar tujuan bisa dicapai dengan mudah dalam penyelesaian soal. Setelah soal telah dijawab, maka kelompok tersebut menyusun bagian-bagian kartu yang telah diacak sesuai dengan jawaban yang benar. Kelompok yang paling banyak mendapatkan skor maka ialah pemenangnya. Hal ini dilakukan sebagai upaya agar peserta didik dilatih kecepatan berpikir dan membantu mengembangkan aktivitas sehingga akan memengaruhi hasil belajarnya. Aktivitas belajar mempunyai hubungan yang erat dengan kemampuan kognitif. Kemampuan kognitif peserta didik didapatkan melalui aktivitas belajar yang mereka lakukan sebelumnya (Rachman, 2013). Pada pelaksanaan tindakan dimulai dari siklus I yang dilaksanakan sebanyak dua kali pertemuan. Evaluasi diberikan pada saat pertemuan ketiga dengan memberikan tes hasil belajar yang berupa soal uraian untuk mengetahui sejauh mana tingkat pemahaman dan perkembangan hasil belajar peserta didik setelah menerapkan model pembelajaran Scramble. Adapun tes hasil belajar pada siklus I dengan persentase ketuntasan sebesar 75\% dengan nilai rata-rata 77,25. Nilai tertinggi 96 dan nilai terendah 44 dengan jumlah peserta didik sebanyak 16 orang. Peserta didik yang tuntas belajar sebanyak 12 orang sedangkan peserta didik yang tidak tuntas sebanyak 4 orang. Hasil tes siklus I ini menunjukan bahwa penerapan model pembelajaran Scramble dapat menigkatkan hasil belajar peserta didik. Peningkatan hasil belajar dalam pembelajaran dilihat dari bagaimana peserta didik mengikuti pembelajaran atau lebih memahami materi yang disajikan oleh guru (Mayliana dkk, 2013). Sebelum dilakukannya tindakan hasil belajar peserta didik masih banyak yang tidak mencapai KKM, tetapi setelah dilaksanakannya tindakan dengan menerapkan model pembelajaran Scramble maka hasil belajar peserta didik meningkat 15\%. Hasil tersebut didukung oleh penelitian Sitti Mahnia Siregar (2019) mengatakan bahwa hasil belajar peserta didik pada mata pelajaran IPA meningkat melalui model Scramble di kelas IV MIS Bina.

Pelaksanaan tindakan siklus II dilakukan selama dua kali pertemuan dimana evaluasi dilakukan di pertemuan ketiga dengan memberikan tes hasil belajar yang bertujuan untuk mengetahui sejauh mana tingkatan pemahaman dan peningkatan hasil belajar peserta didik dari siklus I. Adapun perolehan tes hasil belajar siklus II dengan persentase ketuntasan sebesar 81,25\% dengan nilai ratarata sebesar 82,25 . Adapun peserta didik yang tuntas belajarnya sebanyak 13 orang dan peserta didik yang tidak tuntas sebanyak 3 orang. Hasil yang diperoleh peserta didik pada siklus II ini sudah mencapai indikator ketuntasan secara klasikal yakni 70\% sedangkan yang diperoleh mencapai 81,25\%. Artinya penelitian sudah dikatakan berhasil sehingga penelitian ini tidak dilanjutkan lagi pada siklus berikutnya karena hasil belajar Matematika di kelas $\mathrm{V}$ telah meningkat melalui penerapan model pembelajaran Scramble. Hasil tersebut didukung oleh penelitian Isna Fitriana (2017) menyatakan bahwa model pembelajaran Scramble dapat meningkatkan hasil belajar peserta didik pada materi tata nama senyawa di SMAN 1 Bireuen.

\section{SIMPULAN DAN SARAN}

Berdasarkan hasil penelitian tindakan kelas yang dilakukan oleh peneliti diperoleh kesimpulan bahwa penerapan model pembelajaran Scramble dapat meningkatkan aktivitas belajar Matematika peserta didik kelas V. Pada Siklus I pertemuan pertama persentase aktivitas siswa 58\% dan menjadi 67\% pada pertemuan kedua, kemudian mengalami peningkatan pada siklus II pertemuan pertama $79 \%$ dan 83\% pada pertemuan kedua. Selain itu, penerapan model Pembelajaran Scramble juga berpengaruh positif pada peningkatan hasil belajar peserta didik. Dengan materi volume bangun ruang balok dan kubus, rata-rata hasil belajar matematika peserta didik kelas $\mathrm{V}$ meningkat dari 77,25 pada siklus I dengan persentase ketuntasan belajar klasikal $75 \%$ menjadi 82,25 pada siklus II dengan persentase ketuntasan belajar klasikal $81,25 \%$. Hal tersebut menunjukkan bahwa hasil belajar telah mencapai 
KKM Matematika yaitu $\geq 65$ dengan persentase ketuntasan $70 \%$. Namun penelitian ini memiliki limitasi seperti pada pelaksanaannya ada beberapa peserta didik yang agak sulit dimasukkan dalam kelompok yang heterogen sehingga terjadi hambatan dalam melaksanakan langkah-langkah model pembelajaran Scramble. Maka peneliti meminta kepada peneliti selanjutnya sebaiknya dipahami kembali cara penerapan model pembelajaran Scramble, kemudian selalu memperhatikan kondisi dan karakteristik peserta didik agar keterbatasan dalam penelitian ini dapat diminimalisir pada peneliti selanjutnya

\section{DAFTAR RUJUKAN}

Akib, Zainal dkk. (2001). Penelitian Tindakan Kelas Guru SMA, SMP, dan SMK. Bandung: Alam Widya.

Fitriana, Isna. (2017). Penerapan Model Pembelajaran Scramble untuk Meningkatkan Hasil Belajar Peserta didik pada Materi Tata Nama Senyawa di SMAN 1 Bireuen. Skripsi Sarjana. UIN AR-RANIRY DARUSSALAM, Banda Aceh

Handini, Ines Desi. (2012). Penerapan Model Pembelajaran Kooperatif Tipe Scramble Pada Materi Segi Empat Untuk Meningkatkan Aktivitas dan Hasil Belajar Matematika Peserta didik Kelas VII di SMP Negeri 1 Alian Tahun 2011/2012. Skripsi Sarjana. Universitas Muhammadiyah Purworejo, Purworejo.

Mirjanah, Mita, dkk. (2017). Peningkatan Aktivitas dan Hasil Belajar Peserta didik Melalui Penerapan Model LEARNING CYCLE 7E (LC 7E) Pada Pembelajaran Biologi Kelas X Ipa 4 SMA Negeri 1 Bringin Tahun Pelajaran 2016/2017.Jurnal Varia Pendidikan, 29 (1), 19.

Mudyahardjo, Redja. (2012).Pengantar Pendidikan. Jakarta: PT Raja Grafindo Persada

Muzakar. (2014). Kinerja Kepala Sekolah dalam Meningkatkan Mutu Lulusan pada Madrasah Tsanawiyah Negeri Meureubo. Jurnal Ilmiah Islam Futura, 4, 110-133.

Nursenda, Fiana Puspa. (2018). Penerapan Model Pembelajaran Kooperatif Tipe Scramble Untuk Meningkatkan Hasil Belajar IPS Peserta didik Kelas V SDN Perning Mojokerto. Jurnal PGSD, 6, 229.

Purwandari, N. (2015). Peningkatan Keterampilan Proses dan Hasil Belajar IPA melalui Penerapan Model Pembelajaran Berbasis Proyek pada Peserta didik Kelas IV SD N 2 Srandakan. Jurnal Pendidikan Gutu Sekolah Dasar, 15, 1-10.

Purwanto, Ngalim. (2009). Prinsip-Prinsip dan Teknik Evaluasi Pengajaran. Bandung: Remaja Rosdakarya.

Republik Indonesia. Undang-Undang R.I. Nomor 20 Tahun2003 Bab II Pasal 3, dalam Undang-Undang dan Peraturan Pemerintah R.I. tentang Pendidikan. Jakarta: Direktorat Jenderal Pendidikan Islam Departemen Agama R.I. 2006.

Sanjaya, Wina. (2013). Strategi Pembelajaran Berorientasi Standar Proses Pendidikan. Jakarta: Kencana Prenadamedia Group.

Sardiman. (2011). Interaksi dan Motivasi Belajar Mengajar. Jakarta: Rajawali Pers.

Sasmita, Nabila. (2013). Analisis Kesalahan Mengerjakan Soal Geometri pada peserta didik Kelas V SD/MI di Kota Jogjakarta. Skripsi Sarjana. UIN Sunan Kalijaga, Yogyakarta. 
Setiawati, Mariani, dkk. (2013). Meningkatkan Aktivitas dan Hasil Belajar Peserta didik Dengan Penerapan Model Pembelajaran Penemuan Terbimbing. Berkala Jurnal Ilmiah, 1(1), 17.

Siregar, Sitti Mahnia. (2019). Upaya Meningkatkan Hasil Belajar Peserta didik Pada Mata Pelajaran IPA Materi Gaya Melalui Model Scramble di Kelas IV MIS Bina Keluarga Jl. Setia Budi No.18 Kel. Indra Kasih Kec. Medan Tembung Kab. Deli Serdang Kota Medan. Skripsi Sarjana. UIN Sumatera Utara, Sumatera Utara.

Sudjana, Nana. (2010). Cara Belajar Peserta didik Aktif dalam Proses Belajar Mengejar.Bandung: Sinar Baru Algensindo.

Supardi. (2006). Penelitian Tindakan Kelas. Jakarta: Bumi Aksara.

Umar, Husein. (2014). Metode Penelitian Untuk Skripsi dan Tesis Bisnis. Jakarta: Rajawali Pers. 